\title{
Function Words in Edgar Alan Poe's A Dream Within A Dream: A Psychological Analysis
}

\section{Assist Prof. Dr. Lanja Abdul razzaq Dabbagh}

Department of English, College of Languages, Salahaddin University, Erbil, Kurdistan Region, Iraq lanja dabbagh@yahoo.com, lanja.dabbagh@su.edu.krd,

\section{ARTICLE INFO}

Article History:

Received: $15 / 2 / 2021$

Accepted: 28/3/2021

Published: Winter 2021

Keywords:

Function words, psychological analysis, surface meanings, hidden meanings,

literature

Doi:

10.25212/lfu.qzj.6.1.37

\begin{abstract}
Language in general reflects the influence of the psychological state in human beings when they communicate with each other. All the aspects of language are involved in producing the state of mind of the speaker, including the simplest parts of speech. Function words are not an exception to this process. That is why there is a powerful connection that joins the function words with the psychological state of the speaker specially in literature, because in literature every word, article, punctuation carries both surface and hidden meanings. These hidden meanings are related to the psychological condition of the producer. Function words also reflect the cognitive architecture of the speaker. The study is supporting the cognitive reflection model. The aim is to show that the psychological state of the poet Edgar Alan Poe affected his use of the function words in his poem A Dream Within A Dream. It also aims at showing how it affected his use of function words to convey his message and both the surface and hidden meanings. The conclusions arrived at depend on the social psycholinguist's views only.
\end{abstract}

\section{INTRODUCTION}

Communication is essential for human beings in every aspect of life. Language is used to communicate whatever we like to express. New nouns, verbs, and adjectives enrich every vocabulary whenever required. Nevertheless, function words remain the same. Languages go through changes through time but there are fixed which do not experience these changes. These fixed words are essential in every 


\section{QALAAI ZANISTSCIENTIFIC JOURNAL \\ A Scientific Quarterly Refereed Journal Issued by Lebanese French University - Erbil, Kurdistan, Iraq \\ Vol. (6), No (1), Winter 2021}

LF U

ISSN 2518-6566 (Online) - ISSN 2518-6558 (Print)

language. Even more important is their use and the mechanism used by individuals in the process of using them.

The current research aims at relating language in general and function words in particular to the psychological state of the user. Social psychologists are aware of the fact that there are shortcomings in self-reports. Due to the psychological conditions of the speaker at that particular moment. The fact is that the utterance used by individuals to express thoughts about themselves are but concepts established by themselves than actual facts of their true thoughts and feelings. This is transferred to the language they are using.

Changing communication aims and contexts may control function word usage. The fact that the psychological conditions of individuals have a strong impact on the different use of function words. This is an important finding that will be shown through the analysis of the selected poem. The work starts with showing the connections that relate the psychological condition of the writer with the use of function words to transfer through the levels of analysis.

\section{Function Words}

(Baayen, Piepenbrock, \& Gulikers, 1995) state that function words are all the words used in a text to link other syntactic elements; they are, for example pronouns and conjunctions among others. The number of function words in English vocabulary is rather small if compared to the content words (Rochon, et al, 2000). It is difficult for English language learners to gain the mastery of using them (Weber-Fox \& Neville, 2001). These function words are the same, they do not change as much as the other parts of language. All languages go through changes as time goes by due to many reasons, but function words stay the same.

For some scientific clues, we need to know the biological production to language in order to relate language in general and function words in specific to the functions of the brain; thus, the psychological conditions of individuals (language users). Human brain is considered to be large if compared to animals. Damasio, 1995, among others, emphasizes that the frontal lobe is guiding our social behaviors. We could conclude that most social emotions are highly dependent on the whole front 


\section{QALAAI ZANISTSCIENTIFIC JOURNAL \\ A Scientific Quarterly Refereed Journal Issued by Lebanese French University - Erbil, Kurdistan, Iraq \\ Vol. (6), No (1), Winter 2021}

ISSN 2518-6566 (Online) - ISSN 2518-6558 (Print)

lobe. Since language is a social behavior it is strongly related to the job of the brain's front lobe like any other behavior (Gazzaniga, 2005). In general, most of language functions are situated in the front and the temporal lobes. When there are brain damages caused by tumors or accidents, the lobes get affected which leads to disabilities of some functions of the body, language comprehension and production among them. If the damage is on the Wernicke's area, the compression and the production of language will be highly affected. The degree will vary according to the type, shape, amount of the damage. Some of these damages cause hesitation, some cause the control of using function words. All these damages affect the psychological condition of the person suffering. Those people with brain damages affecting language areas will force be to live a completely different social life that will also affect their psychological states (Miller, 1995). The above indicates that function words are subjects to questions when there is a brain damage. The majority of those who suffer from brain damage misuse function words or completely are unable to use them.

For the learners of English, function words are difficult to control and they often make mistakes in using them. For native English users, function words are used fluently. If they make mistakes in using them, they are not aware of them. That is why when linguists investigate function words in English written and spoken language, they relate the mistakes in using function words to slips of the tongue or to the psychological condition of the users (Fazio \& Olson, 2003). The analysis in the present paper involves a literary work

\section{The Psychological Effects on the Use of Function Words}

According to Stirman \& Pennebaker, (2001) when analyzing the poetry of suicidal versus, we could see that they use first person singular pronouns more often than poets who did not kill themselves. Generally, we could realize that the poets who have the suicidal ideas are more self-observers than the others who have no intentions to commit suicide. Actually, those suicidal poets, like Poe, compose their pomes concentrating on themselves rather than others.

Campbell \& Pennebaker, 2003 state that "using an alternative text analysis method based on latent semantic analysis, it was found out that people who 


\section{QALAAI ZANISTSCIENTIFIC JOURNAL \\ A Scientific Quarterly Refereed Journal Issued by Lebanese French University - Erbil, Kurdistan, Iraq \\ Vol. (6), No (1), Winter 2021}

LF U

ISSN 2518-6566 (Online) - ISSN 2518-6558 (Print)

alternated in their use of personal pronouns" are more psychologically subjectives. They also comment that "when asked to write about emotional upheavals in their lives they switch from high rates of "I" to high rates of other personal pronouns" (p.11).

Pronouns and other function words also put forward clues and clues about the truthfulness of statements. There are certain properties in English language, for example, prepositions, are used to draw and highlight major differences about word classes. This class of words is the class that contains conjunctions and function words. They own a cognitive complexity if compared with other classes (Pennebaker \& King, 1999). A number of investigations were carried on people who uses the pronoun I in their utterance when asked to be honest. Thus, there is a relation between honesty and the use of first-person singular in the sense that this usage give evidence that the speaker is honest. (Newman, et al, 2003). So, people are more aware of how they engage particular words when telling the truth, which leads to the assumption that there is a rather complex cognitive description of truth.

According to Pennebaker \& Davis, 2006 in an interaction between two people, the psychological conditions of the speakers determine which of the function words is largely used. They found out that the first-person singular pronouns among other function words are highly used. These pronouns have a strong relation with the speaker's choice of words. This choice is strongly related to the psychological conditions of the participants of any interaction.

\section{A Dream Within A Dream (1849)}

Like most of Poe's works, "A Dream Within A Dream", is a complicated search in the mind of the poet, the mind of the reader, and the mind of a third person. It is one of his most analyzed poems literarily. When reading the poem, one cannot figure out whether or not it is real, or just an illusion felt and imagined by the poet. The poet is directing his speech to someone, could be his lover. He is telling the person and us as readers that he has an idea which makes him almost certain that his life is actually a dream. He also thinks that his life might be a dream but inside another dream. This assumption leads to the fact that there is nothing true in reality. As the poem goes 
by, Poe talks about the sand which slips away from his hand and fingers. He is thinking that all the beautiful things in life will vanish and he will not be able to save any of them. Poe engages figures of speech to convey the idea that we could never be certain if life is a reality or it is just a dream. This poem is considered to be one of the most beautiful pieces composed by Poe (Sova, 2001).

If we take a glance at the phrase "a dream within a dream", the title of the poem, we could understand that the poet is trying to tell us something. It might be an ambiguous idea, yet we never stop amazed by Poe's talent. He is trying to tell us that reality is but a dream. We should be aware that nothing is real in life. That is why our lives could be thought of as a dream, a dream which could be sad or happy. In his case it is a sad dream because he is leaving, and everything is fading away. The poem is not a dream, but the poet is dreaming of his life inside another dream. (Silverman, 1991).

\section{The Analysis}

Take this kiss upon the brow!

And, in parting from you now,

Thus much let me avow--

You are not wrong, who deem

That my days have been a dream;

Poe is parting from the person whom he kisses on the brow. When leaving, the poet, confirms that he wants to convey a specific wish to her. A wish that is dear to his heart. He wants to say to her that all his life has been a dream and it seems that this is what she told him earlier. So, either he really has been dreaming (in which case, the poem is trippy), or she is indicating that when they spend time with each other was nothing but a wonderful dream. The poet is confused, he does not know whether what he experienced with his lover is a dream or a reality. This shows that the poet is living in a fantasy world affected by his emotions and psychological state of mind. His use of the article the indicates an uncertainty, why he did not use instead: her, your, or even, the beloved. The poet uses And to confirm the idea that he is really leaving 
her. The article $a$ is used to specify the fact that the dream is but one dream among other dreams by the poet.

Yet if hope has flown away

In a night, or in a day,

In a vision, or in none,

Is it therefore the less gone?

Poe does not want to leave his beloved. He has planned to leave after kissing her on her brow, yet he is not ready to do so. He wants to tell her something very important. He wishes to talk to his lover about hope and what lies beneath it. He wants to tell her that there is no hope, it is gone, and she should never think about it anymore. He, also, wants to let her know that he does not care if hope leaves him. He is leaving her which perhaps means leaving behind a fantasy or a dream. The repetition of the use of the article $a$ shows uncertainty and vagueness in the poem. The poet himself is tentative of his hope that is why he uses the indefinite article a. he is not self-assured about his dream, his hope, and his life. This indicates the sad mood of the poet reflected in his words.

\section{All that we see or seem}

Is but a dream within a dream

The lover said to the poet that his life was a big dream. He is approving this assumption by saying that not just his life alone is a dream, it is all of our lives are dreams and it is not just a dream, but a dream within a dream. That makes it even more vague. The implications of this mystery; a dream within a dream, are philosophical. If all what the poet is claiming is true, then even if we come out from the dream, we will still be in a dream because it is a dream inside another dream. Thus, there is no place of hope whatsoever. Poe is using the figures of speech to finish the lines of the first stanza. 


\section{I stand amid the roar \\ Of a surf-tormented shore, And I hold within my hand \\ Grains of the golden sand--}

The poet begins the second stanza by telling us his position near the sea. He is at the shore with sand in his hand. He is watching the sand running away from his figures. The sound of loud waves to the poet is like the lion's roar. The sounds are so loud and powerful just like life itself. Now, he is in doubt whether what he is experiencing is a dream, or it is actually his reality. Poe uses the article I to confirm that it is he who is experiencing this reality or dream of the sand slipping away from his fingers; life is slipping away.

How few! yet how they creep

Through my fingers to the deep,

While I weep--while I weep!

The poet uses the word few probably to indicate to grains of sand because he can only hold onto a few grains at a time, perhaps bits of reality in his dream. This is an evidence that the poet is suffering from a pessimistic view of the world, for him few grains equals few hopes. Even this little hope, like the grains, creep through the poet's fingers down to the deep, or the ocean. He just cannot hold on to them. Ocean is metaphorically referred to as the depth, and by telling us that grains of sand creep that is personification. At the same time the poet is weeping while the sand slips through his fingers. If holding onto the sand is his way of relating to reality-to something physical-then it makes sense that he's feeling bummed. His grip on reality, like the sand, is slipping away from his fingers which causes him a lot of frustration that is why he is repeating the clause while I weep. The pronoun I is repeated also to provide hints about the truthfulness of statements.

O God! can I not grasp

Them with a tighter clasp? 
O God! can I not save

One from the pitiless wave?

The poet drives home the point about his depression, anger, and irritation. He is begging God to help him save some sand. As if he is begging for survival. He is wondering why he cannot keep some sand. Why is it so hard to keep holding the sand? This is an evidence that the poet is depressed and he has no hope. The cruel wave does not let him keep the sand. As if he is telling us that there is a power that does not let us dream. The pronoun I is used many times to show the uncertainty and the depression the poet experience. The article $a$ in a tighter clasp shows the poet's psychological state that he only wants one grasp; one chance; one hope. It proves that he is very desperate. At the same time, he uses the article the in the pitiless wave as if he is telling the readers that there is a specific force that takes away the sand.

Is all that we see or seem

But a dream within a dream?

Here we could see that there is a glance of hope. Although the poet is hopeless, yet he never stops giving up. The poet ends the poem with a question related to the main idea he started with and that is we all live in a dream and that dream is actually happening in another dream. Using the article, $a$ twice is to show that he is insisting on the fact that there is only one dream inside another dream. The poet is so sad about this fact, but he does not want to confess it. He has hope but the hope is fading away. This brings him to the ultimate phase of depression.

\section{Conclusions}

1. Language is the medium that conveys the actual thoughts and feelings of the inner sides of human beings. The choices of words reflect the psychological conditions they are experiencing. Function words are no exceptions. They are linguistic tools which are used by every individual to express themselves. The selected poem transfers these words by expressing the psychological meanings they behold. 
2. To Edgar Alan Poe life is nothing due to the fact that everything will vanish at the end. Nothing lasts, and when we look back on those things, it feels like a dream. Eventually, it leads to the concept that there is a dream inside a dream. Both of them are dreams and both of them fade away and desperate. In the first extract, we could see that his use of the article the shows the uncertainty which is confirmed throughout the poem, why he did not use instead for example: her, your, or even, the beloved. Poe also uses And to confirm the idea that he is really leaving her; it is a confirmation of the true departure. At the same time the article $a$ is used to specify the fact that the dream is but one dream among other dreams experienced by the poet.

3. The repetition of the use of the article a shows the uncertainty and vagueness in the poem. The poet himself is uncertain of his hope for this reason he uses the indefinite article a. he is not confident about his dream, his hope, and his life. This signifies the sad mood of the poet reflected in his words.

4. The use of the function words in the poem reflects the psychological state of the poet. They are employed to show the real meaning of the rest of the words. Poe uses the pronoun I to show that the main concern of the poem is to elaborate the true feelings of the poet. This is a way to strengthen interaction between him and the readers. Poe uses the article / to confirm that it is he who is experiencing this reality or dream of the sand slipping away from his fingers; life is slipping away. Later, the pronoun / is repeated also to provide hints about the truthfulness of statements.

5. The function words in the poem confirm that the poet is telling the truth about what he feels. He is feeling that by using them makes the poem more personal and, at the same time, are more likely to describe his story (his view about life) in a more cognitively complex way. He uses the article a in a tighter clasp to describe the clasp; his struggle being weak and single; one chance; one hope. It proves that he is very desperate. Meanwhile, he uses the article the in the pitiless wave confirming that there is a specific force that takes away the sand, his life, his dream, his lover.

6. Poe is extremely clever in choosing and using words. The use of function words is another brilliant technique to implement the use of language in delivering 


\section{QALAAI ZANISTSCIENTIFIC JOURNAL}

A Scientific Quarterly Refereed Journal Issued by Lebanese French University - Erbil, Kurdistan, Iraq

Vol. (6), No (1), Winter 2021

ISSN 2518-6566 (Online) - ISSN 2518-6558 (Print)

the poem's theme and the poet's message. In the concluding lines, the poet phrases the idea as a question. Using the article, $a$ twice to show that he is insisting on the fact that there is only one dream inside another dream. Yet, we could imagine maybe he is just getting more desperate because after all, he has lost hope. The poet cannot be sure that all that he experienced is but a dream within a dream.

\section{REFERENCES:}

Baayen, R. H., Piepenbrock, R., \& Bulickers, L. (1995). The CELEX Lexical Database [CD ROM]. Philadelphia: Linguistic Data Consortium, University of Pennsylvania.

Campbell, R. S., \& Pennebaker, J. W. (2003). 'The secret life of pronouns: Flexibility in writing style and physical health'. Psychological Science, 14, 60-65.

Damasio, A. R. (1995). Descartes' error: Emotion, reason and the human brain. New York: Harper Collins.

Fazio, R. H., \& Olson, M. A. (2003). 'Implicit measures in social cognition research: Their meaning and use'. Annual Review of Psychology, 54, 297-327.

Gazzaniga, M. S. (2005). The ethical brain. New York: Dana Press.

Miller, G. A. (1995). The science of words. New York: Scientific American Library.

Newman, M. L., Pennebaker, J. W., Berry, D. S., \& Richards, J. M. (2003). 'Lying words: Predicting deception from linguistic style'. Personality and Social Psychology Bulletin, 29, 665-675.

Pennebaker, J. W., \& Davis, M. (2006). Pronoun use and dominance. Unpublished data. Department of Psychology, University of Texas at Austin, Austin, TX.

Pennebaker, J. W., Groom, C. J., Loew, D., \& Dabbs, J. M. (2004). 'Testosterone as a social inhibitor: Two case studies of the effect of testosterone treatment on language'. Journal of Abnormal Psychology, 113, 172-175.

Pennebaker, J. W., \& King, L. A. (1999). 'Linguistic styles: Language use as an individual difference'. Journal of Personality and Social Psychology, 77, 1296-1312.

Rochon, E., Saffran, E. M., Berndt, R. S., \& Schwartz, M. F. (2000). 'Quantitative analysis of aphasic sentence production: Further development and new data'. Brain and Language, 72 , 193-218.

Silverman, Kenneth. (1991) Edgar A. Poe: Mournful and Never-ending Remembrance. New York: Harper Perennial.

Sova, Dawn B. (2001). Edgar Allan Poe: A to Z. New York: Checkmark Books.

Stirman, S. W., \& Pennebaker, J. W. (2001). 'Word use in the poetry of suicidal and nonsuicidal poets'. Psychosomatic Medicine, 63, 517-522. 
Weber-Fox, C., \& Neville, H. J. (2001). 'Sensitive periods differentiate processing of open- and closed-class words: An event-related brain potential study of bilinguals'. Journal of Speech, Language, and Hearing Research, 44, 1338-1353.

\section{ووشهكانى كار له (خهون له نيّوان خهوندا) لهلايهن يُّيدِكار ئالان يوّ}

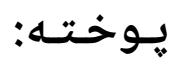

ووشهكانى كار كاريكهرى بارى دهروونى مروّف ييشاندهدهن. لينكيّكى بههيز ههيه له نيّوان

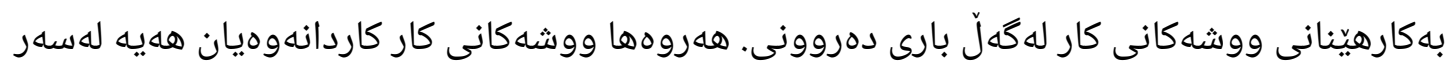
زانينى تهلارسازى قسه كهر. ئهم خويّندنهوهيه يشتخگيرى له موّديلى كاردانهوهى زانين دهكات. ئامانج لهوهدايه كه بارى دهروونى شاعير ئيّدكار ئالان يوّ كاريكهرى كردووه لهسهر بهكارهيّنانى ووشهكانى كار له شيعرى (خهون لهنيّوان خهوندا). به يشتبهستن لهسهر بنجينهى ئه خويْندنهوهيه شيكردنهوهكه تيشك دهخاته سهر بهكارهيّنانهكانى

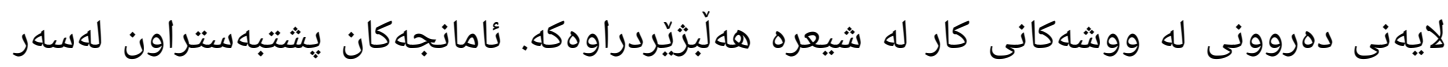
بنجينهى زمانزانى كوّمهلايهتى دهروونى. ئهم خويَندنهوهيه ههولِّيكه بوّ دياريكردنى كاريكهرى بارى

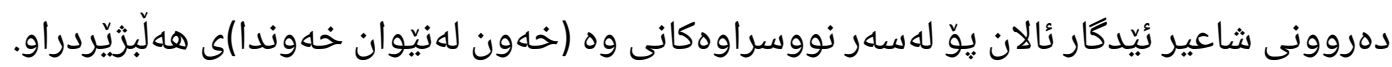

\section{الكلمات الوظيفية في (حلم داخل حلم) لأدغار الان بو: دراسة نفسية}

الملخص: الكلمات الوظيفية تعكس تأثير الحالة النفسية للانسان. هنالك حلقة وصل قوية بين استعمال الكلمات الوظيفية و الحالة النفسية. الكلمات الوظيفية أيضاً تعكس العمارة المعرفية للمتكلم. الدراسة تؤيد فكرة النموذج المعرفي. الهدف هو تبيان أن الحالة النفسية للثاعر أدغار الان بو تؤثر في استعماله للكلمات الوظيفية في شعره (حلم داخل حلم). إستتاداً على خلفية الدر استة, التحليل يُركز على الاستعمال النفسي للكلمات الوظيفية المستخدمة في الشعر المختار .

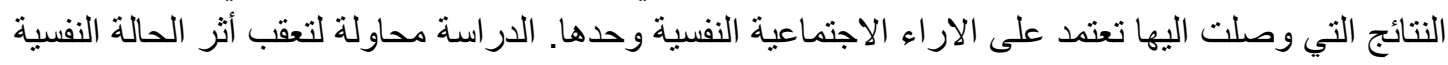
للثاعر في كتاباته من خلال الشعر المختار (حلم داخل حلم). 